\title{
Distribution of coagulase-negative Staphylococcus species from milk and environment of dairy cows differs between herds
}

\author{
V. Piessens, ${ }^{\star 1}$ E. Van Coillie, ${ }^{\star}$ B. Verbist, ${ }^{*}$ K. Supré,† G. Braem,‡ A. Van Nuffel, ${ }^{\star}$ L. De Vuyst,‡ M. Heyndrickx, ${ }^{\star}$ \\ and S. De Vlieghert \\ *Institute for Agricultural and Fisheries Research (ILVO), Technology and Food Science Unit, 9090 Melle, Belgium \\ †Department of Reproduction, Obstetrics, and Herd Health, Faculty of Veterinary Medicine, Ghent University, 9820 Merelbeke, Belgium \\ $\ddagger$ Research Group of Industrial Microbiology and Food Biotechnology, Faculty of Sciences and Bioengineering Sciences, Vrije Universiteit Brussel, \\ 1050 Brussels, Belgium
}

\section{ABSTRACT}

In many parts of the world, coagulase-negative staphylococci (CNS) are the predominant pathogens causing intramammary infections (IMI) in dairy cows. The cows' environment is thought to be a possible source for CNS mastitis and this was investigated in the present paper. A longitudinal field study was carried out in 6 wellmanaged dairy herds to determine the distribution and epidemiology of various CNS species isolated from milk, causing IMI and living freely in the cows' environment, respectively. In each herd, quarter milk samples from a cohort of 10 lactating cows and environmental samples from stall air, slatted floor, sawdust from cubicles, and sawdust stock were collected monthly $(\mathrm{n}=13)$. Isolates from quarter milk samples $(\mathrm{n}=134)$ and the environment $(\mathrm{n}=637)$ were identified to species level using amplified fragment length polymorphism (AFLP) genotyping. Staphylococcus chromogenes, S. haemolyticus, S. epidermidis, and S. simulans accounted for $81.3 \%$ of all CNS milk isolates. Quarters were considered infected with CNS (positive IMI status) only when 2 out of 3 consecutive milk samples yielded the same CNS AFLP type. The species causing IMI were $S$. chromogenes (n $=35$ samples with positive IMI status), $S$. haemolyticus $(\mathrm{n}=29)$, S. simulans $(\mathrm{n}=14)$, and $S$. epidermidis $(\mathrm{n}$ $=6)$. The observed persistent IMI cases $(\mathrm{n}=17)$ had a mean duration of $149.4 \mathrm{~d}$ (range 63.0 to $329.8 \mathrm{~d}$ ). The CNS species predominating in the environment were S. equorum, S. sciuri, S. haemolyticus, and S. fleurettii. Herd-to-herd differences in distribution of CNS species were observed in both milk and the environment, suggesting that herd-level factors are involved in the establishment of particular species in a dairy herd. Primary reservoirs of the species causing IMI varied. Staphylococcus chromogenes and S. epidermidis were rarely found in the environment, indicating that other

Received October 22, 2010.

Accepted March 7, 2011

${ }^{1}$ Corresponding author: Veerle.Piessens@ilvo.vlaanderen.be reservoirs were more important in their epidemiology. For S. haemolyticus and S. simulans, the environment was found as a reservoir, suggesting that IMI with these species were possibly environmental in origin.

Key words: amplified fragment length polymorphism, coagulase-negative staphylococci, environment, cow milk

\section{INTRODUCTION}

In the last 2 decades, mastitis prevention programs (National Mastitis Council, 2009) have resulted in better control of transmission of contagious mastitis pathogens in lactating dairy cows. In many well-managed dairy herds, the obtained decrease in prevalence of IMI caused by contagious major pathogens is, however, associated with a relatively higher proportion of subclinical or mild clinical infections caused by CNS (Tenhagen et al., 2006; Bradley et al., 2007; Piepers et al., 2007). Moreover, CNS are the major cause of IMI in heifers, the future milk producers of every dairy herd (Fox, 2009; Piepers et al., 2010). The change in distribution of mastitis pathogens suggests that current mastitis control measures are less effective in reducing CNS IMI.

In general, CNS induce only a mild inflammatory reaction in infected quarters, as indicated by the modest increase in the milk SCC (Schukken et al., 2009). However, they can be a cause of (mild) clinical mastitis (Waage et al., 1999; Taponen et al., 2006), and quarters infected by CNS have been reported to be at greater risk for infection by major mastitis pathogens (Hogan et al., 1988; Lam et al., 1997). On the other hand, in some studies, CNS IMI protected quarters against new infections by major mastitis pathogens (Rainard and Poutrel, 1988; Matthews et al., 1991). It has also been demonstrated that teat apex colonization with CNS protected heifers against high SCC and new IMI by major pathogens in early lactation (De Vliegher et al., 2003; Piepers et al., 2011). The effect on quarter SCC is species-specific (Supré et al., 2011) and some CNS 
species are able to persist in the udder for long periods (Chaffer et al., 1999; Gillespie et al., 2009), prolonging their influence on the mammary gland. Whether this influence is harmful or advantageous remains unresolved and subject to debate.

A potential drawback of many studies in the past is the classification of CNS as a homogeneous group (Hogan et al., 1988; Nickerson and Boddie, 1994), which could partly explain the aforementioned contradictory findings on the pathogenic or protective role of CNS. In fact, CNS originating from cows include a variety of species with differences in antimicrobial susceptibility (Lüthje and Schwarz, 2006; Sawant et al., 2009) and virulence factors (Park et al., 2011). Therefore, evaluating the epidemiology of individual CNS species is of great importance to understand their respective significance. Based on phenotypic characteristics, species identification of CNS isolates from cows is difficult and often inaccurate (Capurro et al., 2009; Sampimon et al., 2009). In the last few years several genotypic methods have been developed that enable more accurate identification of CNS species (Supré et al., 2009; Piessens et al., 2010; Braem et al., 2011).

The high prevalence of prepartum CNS infections in heifers (Fox, 2009) that have not yet been exposed to the milking process suggests that sources other than the milking machine exist. As CNS are abundantly free-living in dairy herds (Rendos et al., 1975; Matos et al., 1991), we can hypothesize that the cows' environment is a possible source for CNS causing IMI. The aims of the present study were to determine the species distribution of CNS originating from milk and living freely in the cows' environment, evaluate the ability of the different CNS species to cause IMI, and identify their main reservoirs.

\section{MATERIALS AND METHODS}

\section{Herds and Cows}

During the period from May 2008 to May 2009, a longitudinal field study was conducted on 6 Flemish dairy herds (herds A to F). Farms were well-managed and had comparable characteristics reflecting the general situation on Flemish dairy farms. An overview of herd and management characteristics of each farm is given in Table 1. The mean herd size was 70 Holstein cows (range 49 to 87 ) with an average production of 9,368 kg of milk/cow per year (range 7,147 to $11,665 \mathrm{~kg}$ ) and an average bulk milk SCC of 137,725 cells/mL milk (range 85,615 to 202,154 cells $/ \mathrm{mL}$ ). On all 6 farms, cows were housed in freestalls with slatted floors and sawdustbedded cubicles. Sawdust bedding was removed 2 to 3 times a day and replaced by fresh sawdust from a stock stored indoors. Postmilking teat disinfection and dry cow therapy were practiced in all herds.

At the beginning of the study, a cohort of 10 clinically healthy cows was randomly selected in each herd within parity blocks ( 4 heifers, 3 cows of second parity, and 3 cows of third or higher parity). Before the end of the study, 20 out of the 60 cohort cows were culled (ranging from 0 to 5 per herd) for diverse reasons, including problems with lameness, udder health, fertility, or milk production. All cohort cows culled before the 12 th month of the study $(\mathrm{n}=14)$ were replaced by randomly selected herdmates of the same parity. The cohort cows were, on average, 11.2 mo under study.

\section{Sample Collection}

Quarter milk samples were collected aseptically at monthly intervals $(\mathrm{n}=13)$ from the cohort cows according to standard procedures (National Mastitis Council, 1999). Samples were frozen and transported to the laboratory of the Milk Control Centre Flanders (MCC, Lier, Belgium) for bacteriological examination. In addition to the monthly milk samples taken from the cohort cows, extra samples were taken when the farmer noticed clinical signs in a quarter (any visual abnormality of milk or the udder). Clinical milk samples were taken both from cows of the cohort and from cows outside the cohort. The average overall incidence rate of clinical mastitis (IRCM; all pathogens) was calculated as described by Barkema et al. (1998).

Environmental samples were taken once a month (n $=13$ ) in each farm for isolation of CNS. Four different sample types were chosen in proximity to the cows: air in the freestall, slatted floors, used sawdust bedding from cubicles, and unused sawdust from the stock. For isolation of staphylococci from the air in the freestall, blank air strips (Biotest, Dreieich, Germany) were filled aseptically with mannitol salt agar (MSA, BD Biosciences, San Jose, CA), and kept at $4^{\circ} \mathrm{C}$ until further use. At the time of sampling, an MSA-filled strip was removed from the sterile package, placed in the RCS Standard air sampler (Biotest), and exposed for $1 \mathrm{~min}$, which is equal to sampling of $40 \mathrm{~L}$ of air. The slatted floor was sampled by walking over a whole corridor while wearing polypropylene Sekuroka overshoes (Fiers, Kuurne, Belgium), after which both overshoes were transferred to a sterile stomacher bag $(180 \times 300 \mathrm{~mm}$, Medical Lab Service, Menen, Belgium). Used sawdust samples were collected from the back one-third of $10 \%$ of the cubicles. Samples of the sawdust stock were collected at 5 random places in front of the stock using a sample bore $(5.6 \mathrm{~cm}$ diameter, $50 \mathrm{~cm}$ long). Per herd and per sample type, collected sawdust was commingled and a subsample was transferred to a sterile stomacher 


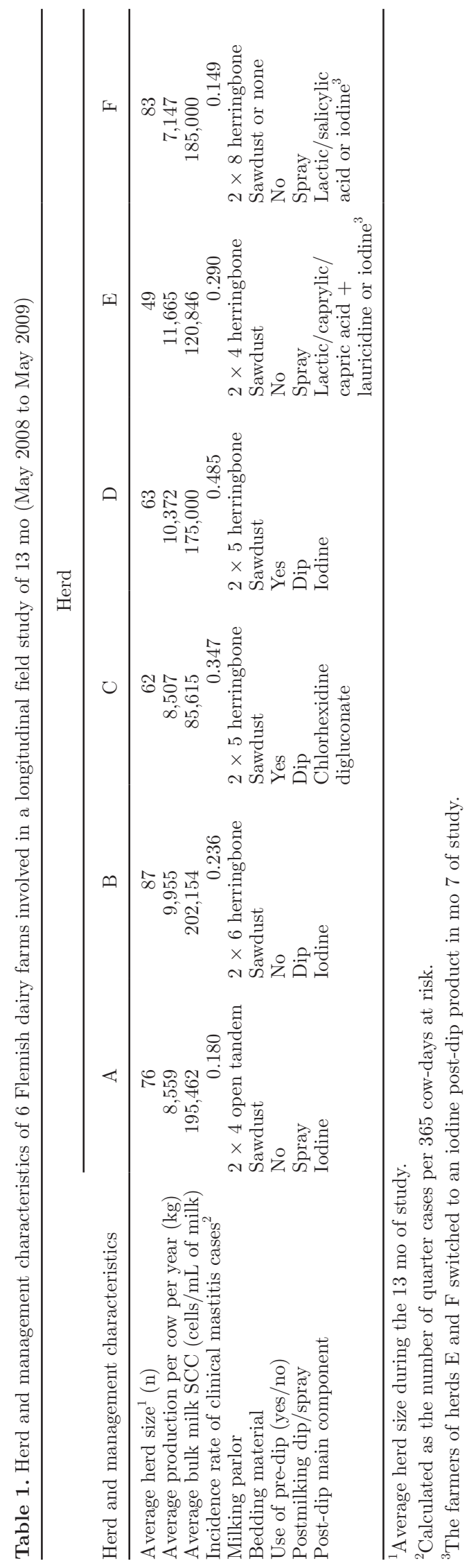

bag. In one herd (herd F), no sawdust samples were collected during the first 5 mo of the study, as the farmer did not use any bedding material in the cubicles at that time. All environmental samples were stored at $4^{\circ} \mathrm{C}$ and transported on the same day to the laboratory for processing.

\section{Sample Processing and Isolation of CNS}

Quarter Milk Samples. Bacteriological culture of quarter milk samples and bacterial identification was done in the Milk Control Centre Flanders as recommended by the National Mastitis Council (1999). Briefly, $0.01 \mathrm{~mL}$ of each quarter milk sample was spread on a quadrant of a blood-esculin agar plate and incubated aerobically at $37^{\circ} \mathrm{C} \pm 1^{\circ} \mathrm{C}$ for $36 \mathrm{~h} \pm 12 \mathrm{~h}$. A quarter was considered culture-positive when growth of $\geq 1$ colony was detected. A sample was considered contaminated when 3 or more dissimilar colony types were observed. Phenotypic differentiation of bacterial species was done as described by Piepers et al. (2007). Staphylococci were identified presumptively based on colony morphology, Gram stain, and positive catalase test. Staphylococcus aureus was differentiated from other Staphylococcus spp. based on morphology, pigmentation, hemolysis, and DNase activity. All nonStaphylococcus aureus staphylococci were a priori considered as CNS. For milk samples yielding at least 3 CNS colonies $(\geq 300 \mathrm{cfu} / \mathrm{mL}), 2$ colonies were picked and transferred to tryptone soy agar (TSA, Oxoid Ltd., Basingstoke, UK) for further identification. When more than one type of CNS colony was present, more colonies were picked. The TSA plates were incubated at $37^{\circ} \mathrm{C}$ for $18 \mathrm{~h}$.

Environmental Samples. On the same day of sample collection, exposed air strips were incubated at $37^{\circ} \mathrm{C}$ for 24 to $48 \mathrm{~h}$. Of each sawdust sample, $25 \mathrm{~g}$ was weighed and put in a new sterile stomacher bag. Overshoes were transferred to separate sterile stomacher bags. To each sawdust sample and overshoe, $225 \mathrm{~mL}$ of brain heart infusion broth (Oxoid Ltd.) $+7.5 \% \mathrm{NaCl}$ was added. Sawdust samples were homogenized for 1 min in a stomacher, and overshoes were massaged by hand for $1 \mathrm{~min}$ for equal distribution of the medium. Samples were then incubated for $20 \mathrm{~h} \pm 4 \mathrm{~h}$ at $37^{\circ} \mathrm{C}$ for selective enrichment of staphylococci. The next day, dilution series of the enrichment media were made in Ringers solution (Oxoid Ltd.), $100 \mu \mathrm{L}$ of dilutions $10^{-2}$ to $10^{-5}$ were spread by use of sterile glass beads (2.5-3.5 mm, VWR International, West Chester, PA) on MSA plates, which were incubated for $20 \mathrm{~h} \pm 4 \mathrm{~h}$ at $37^{\circ} \mathrm{C}$. After incubation, Staphylococcus-like colonies were picked up from MSA plates and strips and were streaked onto TSA. Choice of colonies was random but 
based on dissimilar colony morphology and pigmentation. More colonies were picked from agar plates and strips with more diverse bacterial growth. The TSA plates were further incubated for $18 \mathrm{~h}$ at $37^{\circ} \mathrm{C}$ and checked for purity the next day.

\section{Identification of CNS Isolates}

Confirmation of CNS Identity. A crude DNA preparation was made for all isolates from milk and for a random selection of 4 isolates per environmental sample with dissimilar colony morphology and pigmentation. A few fresh colonies were suspended in $45 \mu \mathrm{L}$ of sterile HPLC water plus $5 \mu \mathrm{L}$ of lysostaphin $(1 \mathrm{mg} / \mathrm{mL}$; Sigma-Aldrich, St. Louis, MO) and incubated at $37^{\circ} \mathrm{C}$ for $10 \mathrm{~min}$. Next, $150 \mu \mathrm{L}$ of Tris- $\mathrm{HCl}(0.1 \mathrm{M}, \mathrm{pH} 8.0)$ plus $5 \mu \mathrm{L}$ of proteinase $\mathrm{K}(2.5 \mathrm{mg} / \mathrm{mL}$; Promega Corporation, Madison, WI) were added, and the suspensions were incubated at $60^{\circ} \mathrm{C}$ for 10 min followed by $90^{\circ} \mathrm{C}$ for $5 \mathrm{~min}$. Cell lysates were vortexed for $1 \mathrm{~min}$, centrifuged at $14,000 \times g$ for $1 \mathrm{~min}$, and kept at $-20^{\circ} \mathrm{C}$ until further use. To confirm the isolates as Staphylococcus species and to overrule $S$. aureus identity, a duplex PCR was performed. Two primer pairs described previously by Mason et al. (2001) were used, the first pair targeting the Staphylococcus genus-specific 16S rRNA gene (fragment of $791 \mathrm{bp}$ ) and the second primer pair targeting the $S$. aureus-specific clfA gene (fragment of $638 \mathrm{bp}$ ). The PCR was performed in a $25-\mu \mathrm{L}$ reaction mixture containing $1 \mu \mathrm{L}$ of cell lysate, $50 \mathrm{pmol}$ of each primer (Eurogentec, San Diego, CA), $1 \times$ PCR buffer II (Applied Biosystems, Foster City, CA), $1.5 \mathrm{mM} \mathrm{MgCl}_{2}, 0.1$ mmol of each dNTP, and $1 \mathrm{U}$ of AmpliTaq Polymerase (Applied Biosystems). Thermal cycling conditions were 1 min at $95^{\circ} \mathrm{C}, 30$ cycles of $15 \mathrm{~s}$ at $95^{\circ} \mathrm{C}, 15 \mathrm{~s}$ annealing at $60^{\circ} \mathrm{C}$, and $30 \mathrm{~s}$ elongation at $72^{\circ} \mathrm{C}$, and a final elongation step at $72^{\circ} \mathrm{C}$ for $8 \mathrm{~min}$. Fragments were analyzed by electrophoresis on $1.5 \%$ (wt/vol) agarose gels. In each executed PCR run, a positive $S$. aureus control (S. aureus ssp. aureus DSM $20231^{\mathrm{T}}$ ), a positive CNS control (S. auricularis ATCC $33753^{\mathrm{T}}$ ), and a negative control (water) were co-analyzed.

Selection of Isolates for AFLP Genotyping. All isolates considered as CNS by PCR were subsequently analyzed by a rapid fingerprinting technique to avoid redundancy in the CNS collection. Random amplification of polymorphic DNA (RAPD)-PCR was done on $1 \mu \mathrm{L}$ of cell lysate using the primer D11344 and PCR conditions as described by Fitzgerald et al. (1997). The RAPD-PCR fragments were separated on $2 \%$ (wt/vol) Seakem LE agarose gels (Lonza, Basel, Switzerland) at $100 \mathrm{~V}$ for $75 \mathrm{~min}$, and RAPD fingerprints of isolates originating from the same milk sample or the same environmental sample were compared visually. When identical RAPD fingerprints were observed, only one isolate per sample was retained in the final CNS collection. Selected CNS isolates were subcultured on TSA for another $18 \mathrm{~h}$ at $37^{\circ} \mathrm{C}$ and stored as frozen stocks in brain heart infusion broth (Oxoid) with $15 \%$ (wt/vol) glycerol at $-80^{\circ} \mathrm{C}$ for further species identification.

Genotyping and Identification of CNS Species. The DNA was prepared and amplified fragment length polymorphism (AFLP) genotyping was done on the final CNS collection as described previously (Piessens et al., 2010). The BioNumerics software version 6.01 (Applied Maths, Sint-Martens-Latem, Belgium) was used for normalization of fingerprints, and the library and identification module was used for calculation of genetic similarities and identification of the field isolates. Species identification was done based on similarity of AFLP fingerprints to entries in the staphylococcal AFLP library, which contained fingerprints of 54 CNS type and reference strains, representing 49 different CNS species and subspecies, and 247 well-identified bovine CNS isolates belonging to $18 \mathrm{CNS}$ species common in cattle (Piessens et al., 2010). Similarities were calculated based on the Pearson product-moment correlation coefficient, and $50 \%$ similarity to a library entry was used as a cut-off for species identification. When an isolate showed less than $50 \%$ similarity to all library entries in the numerical analysis, its fingerprint was visually compared with library strains in a dendrogram constructed with the unweighted pair group method with arithmetic mean (UPGMA) clustering algorithm. Due to different intensities of fingerprints, similarity can be $<50 \%$, although fingerprints visually match. When clearly matching AFLP fingerprints were found in the library, the unknown field isolate was assigned to the corresponding CNS species.

Sequencing of the rpoB Gene. Isolates showing AFLP fingerprints that could not be assigned to any CNS species by numerical analysis or visual comparison were further analyzed by sequencing of the $\operatorname{rpo} B$ gene. Per unknown cluster in the AFLP dendrogram, identification of at least one isolate was done based on rро $B$ gene sequencing as described elsewhere (Supré et al., 2009).

\section{Definition of CNS IMI}

Quarters were diagnosed to have CNS IMI when at least 2 out of 3 consecutive quarter milk samples were found to be culture-positive for the same CNS species with $\geq 300 \mathrm{cfu} / \mathrm{mL}$ and when consecutive isolates had a similar AFLP type. In all other cases, a quarter was considered to be noninfected or of unknown IMI status when no sample was taken in one of the adjacent months (e.g., first sampling, dry period, culling). An 
Table 2. Species distribution of CNS isolates from quarter milk samples taken each month $(\mathrm{n}=13)$ from 10 randomly selected cohort cows per herd in 6 herds

\begin{tabular}{|c|c|c|c|c|c|c|c|}
\hline CNS species & $\begin{array}{l}\text { Total no. of } \\
\text { isolates }(\%)^{1}\end{array}$ & \multicolumn{6}{|c|}{ No. of isolates per herd (no. of cows) ${ }^{2}$} \\
\hline Staphylococcus chromogenes & $41(30.6)$ & $9(2)$ & $6(4)$ & 1 & $7(1)$ & $12(2)$ & $6(2)$ \\
\hline S. epidermidis & $16(11.9)$ & 1 & $5(1)$ & & & $9(6)$ & 1 \\
\hline S. simulans & $15(11.2)$ & & & 1 & & $14(1)$ & \\
\hline S. hominis & $5(3.7)$ & 1 & 1 & & & & $3(2)$ \\
\hline S. auricularis & $3(2.2)$ & 1 & & $2(2)$ & & & \\
\hline S. warneri & $3(2.2)$ & & 1 & & 1 & 1 & \\
\hline S. devriesei & $2(1.5)$ & 1 & & & & & 1 \\
\hline S. equorum & $2(1.5)$ & & & 1 & 1 & & \\
\hline Macrococcus caseolyticus ${ }^{3}$ & $1(0.7)$ & & & & 1 & & \\
\hline S. sciuri & $1(0.7)$ & & & & 1 & & \\
\hline Total & $134(100.0)$ & 18 & 19 & 8 & 31 & 39 & 19 \\
\hline
\end{tabular}

IMI that was present at only 1 sampling was considered a transient case. All other IMI were considered persistent in nature. Duration of persistent IMI cases was calculated by assuming that infections started at the midpoint between the first detection of IMI and the previous sampling, and ended at the midpoint between the last detection of IMI and the next sampling, respectively. When a cow entered or left the study infected, the extra period was calculated as the average number of days between 2 samplings for that herd $(\mathrm{n}=13)$, divided by 2 .

\section{RESULTS}

\section{CNS in Milk}

Based on bacteriological examination, 154 out of 2,580 cohort quarter milk samples $(6.0 \%)$ were culturepositive for CNS $(\geq 100 \mathrm{cfu} / \mathrm{mL})$. Only CNS isolates from milk samples yielding $\geq 300 \mathrm{cfu} / \mathrm{mL}$ were further considered for identification. After duplex PCR (for confirmation of CNS identity) and RAPD analyses (for exclusion of duplicate CNS isolates per sample), 134 CNS isolates originating from 59 different quarters of 37 cows were retained. Six quarter milk samples showed mixed growth of 2 CNS species. All CNS isolates from milk were identifiable to species level by numerical comparison to the AFLP library $(\mathrm{n}=126)$, by visual comparison of clusters in an AFLP dendrogram ( $\mathrm{n}=$ 2 ), or by AFLP and rpoB gene sequencing combined (n $=6)$. In total, 13 species were differentiated, ranging from 5 to 7 different species per herd (Table 2). The predominating CNS species in milk with $\geq 300 \mathrm{cfu} / \mathrm{mL}$ were $S$. chromogenes (30.6\% of all isolates), S. haemolyticus (27.6\%), S. epidermidis (11.9\%), and S. simulans (11.2\%). Staphylococcus chromogenes (isolated from 12 different cows) and S. haemolyticus (13 cows) were the only species isolated in all herds. Staphylococcus epidermidis was isolated in 4 herds (9 cows). Remarkably, $S$. epidermidis was isolated at least once from 6 different cows in herd E. Staphylococcus simulans was isolated in 2 herds, but originated mostly from 1 persistently infected cow in herd E. The more rarely isolated CNS species were restricted to one or a few herds.

\section{CNS IMI}

In the course of the study, 84 individual CNS IMI in 18 quarters of 14 cohort cows (range 0 to 4 cows per herd) were detected (Table 3). They were caused by $S$. chromogenes (n $=35 \mathrm{IMI}), S$. haemolyticus (n $=29)$, S. simulans $(\mathrm{n}=14)$, and $S$. epidermidis $(\mathrm{n}=$ 6) (Table 3). In total, 17 cases of persistent IMI in 16 quarters were detected for which the same causative CNS AFLP-type was repeatedly isolated, and 4 IMI cases in 3 quarters were transient in nature. The mean duration of persistent cases was $149.4 \mathrm{~d}$ (range 63.0 to 329.8 d). The longest persistent CNS infection (329.8 d) was caused by an $S$. chromogenes AFLP type that was isolated 11 consecutive times from the same quarter [Figure 1, herd E, cow 6, left hind quarter $(\mathbf{L H})$ ]. Another cow was persistently infected with S. chromogenes in a quarter in first lactation $(134.2 \mathrm{~d})$ and became infected with another $S$. chromogenes AFLP type $(102.5 \mathrm{~d})$ in its second lactation in the same quarter (Figure 1, herd A, cow 1, LH). Five other quarters of 5 
cows with persistent $S$. chromogenes IMI were detected with a duration ranging from 63.2 to 290.5 d. Staphylococcus haemolyticus was the only CNS species found to cause both transient and persistent infections. In herd D, a heifer was infected with $S$. haemolyticus in 3 quarters [Figure 1, herd D, cow 1, left front $(\mathbf{L F})$, right front $(\mathbf{R F})$, and right hind quarter $(\mathbf{R H})$ ], experiencing 2 persistent ( $74.4 \mathrm{~d}$ in LF, $100.4 \mathrm{~d}$ in $\mathrm{RH}$ ) and 3 transient IMI (1 RH, $2 \mathrm{RF}$ ). The $S$. haemolyticus isolates from the LF quarter showed an AFLP type diverging from the S. haemolyticus library strains and the isolates from the other 2 infected quarters (Figure 1). However, they were confirmed as $S$. haemolyticus by rpoB gene sequencing. A multiparous cow of the same herd was persistently infected with $S$. haemolyticus in 2 quarters for 183.0 and $103.5 \mathrm{~d}$ with another AFLP-type (Figure 1 , herd D, cow 8, LH, RH). One other transient $S$. haemolyticus infection was observed in a multiparous cow of herd $\mathrm{F}$ and 1 persistent infection in a heifer of herd B that lasted for $222.1 \mathrm{~d}$ (data not shown). The 2 quarters with persistent $S$. simulans IMI belonged to the same heifer and were both infected for $214.8 \mathrm{~d}$ with the same AFLP type (Figure 1, herd E, cow 3, LH). Persistent S. epidermidis IMI were found twice, 1 in herd B lasting for $117.6 \mathrm{~d}$ (Figure 1, herd B, cow 9, $\mathrm{RF}$ ) and 1 in herd $\mathrm{E}$ for $63.0 \mathrm{~d}$ (Figure 1, herd E, cow $5, \mathrm{LF})$.

\section{Clinical Cases}

During the study period, 26 quarters with clinical signs were detected from cohort cows and 83 quarters from noncohort herdmates. The average IRCM (all cases) in the herds was 0.281 quarter cases per 365 cow-days at risk (ranging from 0.149 to 0.485 between herds, Table 1). In total, $7.5 \%$ of clinical quarter milk samples ( 7 out of 94 sampled quarters) were positive for CNS growth. Three samples yielded CNS exclusively, and the other 4 showed mixed growth with esculin- positive cocci $(\mathrm{n}=3)$ or Corynebacterium bovis $(\mathrm{n}=$ $1)$. Species distribution of CNS isolates from clinical samples was $2 S$. chromogenes, $1 S$. epidermidis, $1 S$. equorum, and 3 unknown (no isolate was preserved). Both S. chromogenes isolates came from clinical cases yielding CNS exclusively.

\section{CNS in the Cows' Environment}

Coagulase-negative staphylococci were isolated from 75 of 78 (96.2\%) floor samples, from 77 of 78 (98.7\%) air samples, from 65 of $73(89.0 \%)$ used bedding samples, and from 50 of $73(68.5 \%)$ bedding stock samples. After PCR and RAPD analyses, 637 CNS isolates were preserved for further identification. In total, 612 isolates (96.1\%) were identified to species level and 25 isolates $(3.9 \%)$ remained unidentified. Identification results and species distribution over herds are given in Table 4 . Most environmental isolates were readily identifiable by numerical comparison to the AFLP library; namely, 531 out of 637 isolates (83.4\%). Another 81 isolates could be identified by visual comparison of AFLP fingerprints in a cluster $(\mathrm{n}=40)$ or by a combination of rpoB gene sequencing and AFLP clustering ( $\mathrm{n}=$ 41). The CNS species predominant in the environment over all herds were $S$. equorum ( $19.0 \%$ of the isolates), S. sciuri (17.9\%), and S. haemolyticus (16.6\%). The species S. cohnii (5.7\%), S. simulans (5.3\%), S. xylosus $(3.1 \%), S$. devriesei $(2.8 \%)$, and $S$. arlettae $(2.5 \%)$ were also isolated in the environment of each herd, but less frequently. Some notable herd-to-herd differences were observed in relation to species distribution. Several CNS species were chiefly isolated in 1 or 2 herds. Staphylococcus fleurettii was isolated predominantly in the environment of herd E, S. cohnii in herds A and F, S. simulans in herds $\mathrm{C}$ and E, and S. saprophyticus in herd A. In herd E, S. sciuri (3.7\% of environmental CNS isolates) was less common compared with the other herds (11.0 to 28.3\%). Staphylococcus haemolyti-

Table 3. Number of detected IMI caused by CNS species in monthly sampled cows in 6 herds (10 cows/herd)

\begin{tabular}{|c|c|c|c|c|c|c|}
\hline \multirow{2}{*}{$\begin{array}{l}\text { Causative CNS } \\
\text { species }\end{array}$} & \multicolumn{2}{|c|}{ Positive IMI status $^{1}$} & \multicolumn{3}{|c|}{ No. of } & \multirow{2}{*}{$\begin{array}{c}\text { Mean duration (range) } \\
\text { of persistent } \\
\text { IMI cases (d) }\end{array}$} \\
\hline & Transient & Persistent & $\operatorname{cases}^{12}$ & Cows & Quarters & \\
\hline S. haemolyticus & 4 & 25 & 9 & 4 & 7 & $136.7(74.4-222.1)$ \\
\hline S. simulans & & 14 & 2 & 1 & 2 & $214.8(214.8)$ \\
\hline S. epidermidis & & 6 & 2 & 2 & 2 & $90.3(63.0-117.6)$ \\
\hline
\end{tabular}

${ }^{1}$ Number of quarter milk samples with positive CNS IMI status, assigned when at least 2 out of 3 consecutive quarter milk samples were culturepositive for the same CNS species $(\geq 300 \mathrm{cfu} / \mathrm{mL})$, a single positive IMI status was classified as a transient IMI, and recurrent positive IMI status was considered as persistent IMI.

${ }^{2}$ Cases of transient $(\mathrm{n}=4)$ or persistent $(\mathrm{n}=17)$ IMI established by the same CNS amplified fragment length polymorphism (AFLP)-type in a single quarter. 

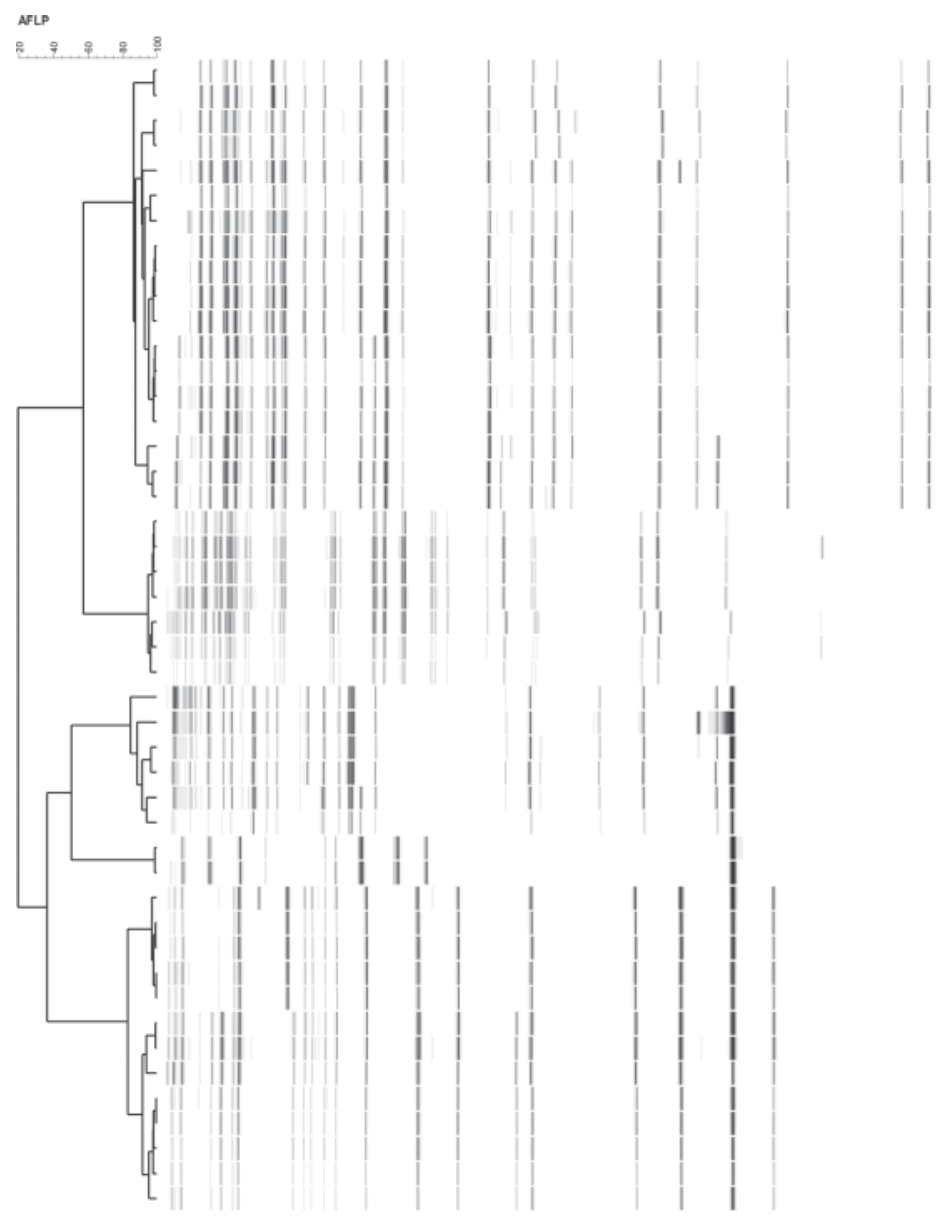

\begin{tabular}{|c|c|c|c|c|c|}
\hline Isolate & Month (1-13) & Herd & Cow & Quarter & \\
\hline mas0816 & 7 & \multirow{11}{*}{ E } & \multirow{11}{*}{6} & \multirow{11}{*}{ LH } & \multirow{11}{*}{ S. chromogenes } \\
\hline $\operatorname{mas} 0934$ & 8 & & & & \\
\hline $\operatorname{mas} 0662$ & 5 & & & & \\
\hline $\operatorname{mas} 0694$ & 6 & & & & \\
\hline $\operatorname{mas} 1087$ & 10 & & & & \\
\hline $\operatorname{mas} 0592$ & 4 & & & & \\
\hline $\operatorname{mas} 0524$ & 3 & & & & \\
\hline $\operatorname{mas} 0938$ & 9 & & & & \\
\hline mas1102 & 11 & & & & \\
\hline $\operatorname{mas} 1221$ & 13 & & & & \\
\hline mas 1111 & 12 & & & & \\
\hline mas0452 & 2 & \multirow{4}{*}{ A } & \multirow{4}{*}{1} & \multirow{4}{*}{ LH } & \multirow{4}{*}{ S. chromogenes } \\
\hline $\operatorname{mas} 0585$ & 4 & & & & \\
\hline $\operatorname{mas} 0526$ & 3 & & & & \\
\hline $\operatorname{mas} 0397$ & 1 & & & & \\
\hline mas0937 & 9 & \multirow{3}{*}{ A } & \multirow[b]{3}{*}{1} & \multirow{3}{*}{ LH } & \multirow{3}{*}{ S. chromogenes } \\
\hline mas 1085 & 10 & & & & \\
\hline mas 1112 & 11 & & & & \\
\hline mas0591 & 4 & \multirow{7}{*}{$\mathrm{E}$} & \multirow{7}{*}{3} & \multirow{7}{*}{ LH } & \multirow{7}{*}{ S. simulans } \\
\hline $\operatorname{mas} 0449$ & 2 & & & & \\
\hline $\operatorname{mas} 0393$ & 1 & & & & \\
\hline $\operatorname{mas} 0523$ & 3 & & & & \\
\hline mas0661 & 5 & & & & \\
\hline $\operatorname{mas} 0689$ & 6 & & & & \\
\hline $\operatorname{mas} 0813$ & 7 & & & & \\
\hline mas 1006 & 9 & \multirow{4}{*}{ B } & \multirow{4}{*}{9} & \multirow{4}{*}{$\mathrm{RF}$} & \multirow{4}{*}{ S. epidermidis } \\
\hline mas 1090 & 10 & & & & \\
\hline $\operatorname{mas} 1097$ & 11 & & & & \\
\hline mas1110 & 12 & & & & \\
\hline mas0693 & 6 & \multirow{2}{*}{ E } & \multirow[b]{2}{*}{5} & \multirow{2}{*}{ LF } & S enidemidis \\
\hline mas 0815 & 7 & & & & S, epidermidis \\
\hline mas0388 & 1 & & 1 & LF & S haemolvticus \\
\hline mas 0445 & 2 & D & & & \\
\hline mas0389 & 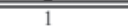 & & & 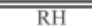 & \\
\hline $\operatorname{mas} 0446$ & 2 & & & $\mathrm{RH}$ & \\
\hline $\operatorname{mas} 0448$ & 2 & D & 1 & $\mathrm{RF}$ & S. haemolyticus \\
\hline $\operatorname{mas} 0532$ & 4 & & & RH & \\
\hline mas 0534 & 4 & & & $\mathrm{RF}$ & \\
\hline$\overline{\operatorname{mas} 0519}$ & $\overline{3}$ & & & & \\
\hline $\operatorname{mas} 0538$ & 4 & & & & \\
\hline $\operatorname{mas} 0936$ & 8 & D & 8 & LH & S. haemolyticus \\
\hline $\operatorname{mas} 0670$ & 5 & & & & \\
\hline $\operatorname{mas} 0686$ & 6 & & & & \\
\hline$\longdiv { \text { mas0685 } }$ & $\overline{c 6}$ & & & & \\
\hline $\operatorname{mas} 0669$ & 5 & D & 8 & RH & S. haemolvticus \\
\hline $\operatorname{mas} 0819$ & 7 & & & & \\
\hline
\end{tabular}

Figure 1. Dendrogram of amplified fragment length polymorphism (AFLP) fingerprints of a selection of the Staphylococcus epidermidis, S. haemolyticus, S. chromogenes, and S. simulans isolates from quarter milk samples of monthly sampled cows. The AFLP types establishing IMI within the same cow or quarter are indicated by boxes. Isolates were identified to species level by comparison of AFLP fingerprints to a staphylococcal AFLP library or by rpoB gene sequencing. Clustering was obtained by the unweighted pair group method with arithmetic averages (UPGMA) of Pearson product moment correlation coefficients, optimization of $1.0 \%$, and curve smoothing of $0.5 \%$. Month of isolation was 1 (May 2008) to 13 (May 2009); quarters are identified as LF (left front), LH (left hind), RF (right front), and RH (right hind).

cus was less common in herds $\mathrm{C}(6.9 \%)$ and $\mathrm{E}(8.3 \%)$ compared with the other herds (15.7 to $26.4 \%$ ).

\section{Distribution of CNS Species over the Different Niches}

When distribution of CNS species over the different niches was compared, certain CNS species tended to favor particular niches (Table 5). Staphylococcus chromogenes and S. epidermidis were predominantly isolated from milk (78.8 and $57.1 \%$ of all isolates, respectively) and less often from environmental samples. Staphylococcus haemolyticus and S. simulans were regularly isolated both from milk and the environment (74.1 and $69.4 \%$ isolates from environment, respectively). Other CNS species were sporadically isolated from milk, but not causing IMI according to our definition. Common species with a mainly environmental origin (90.0 to
$100.0 \%$ of all isolates) were S. equorum, S. sciuri, $S$. fleurettii, S. cohnii, S. devriesei, S. xylosus, S. arlettae, and $S$. succinus. The CNS species in the environment were distributed differently over the sampled locations. Staphylococcus haemolyticus and S. equorum were isolated mostly from stall air (40.6 and $49.6 \%$ of all isolates, respectively), whereas $S$. sciuri and $S$. simulans were isolated on a regular basis from slatted floors and sawdust of the cubicles (72.2 and $67.3 \%$, respectively). Staphylococcus xylosus and S. succinus were isolated mostly from sawdust stock (55.0 and $80.0 \%$, respectively).

\section{DISCUSSION}

In this longitudinal field study, distribution of CNS species isolated from quarter milk samples and the cows' environment was determined in 6 herds. The 
Table 4. Species distribution of CNS isolates from environmental samples (stall air, slatted floors, sawdust from cubicles, and sawdust stock) taken monthly $(\mathrm{n}=13)$ on 6 herds

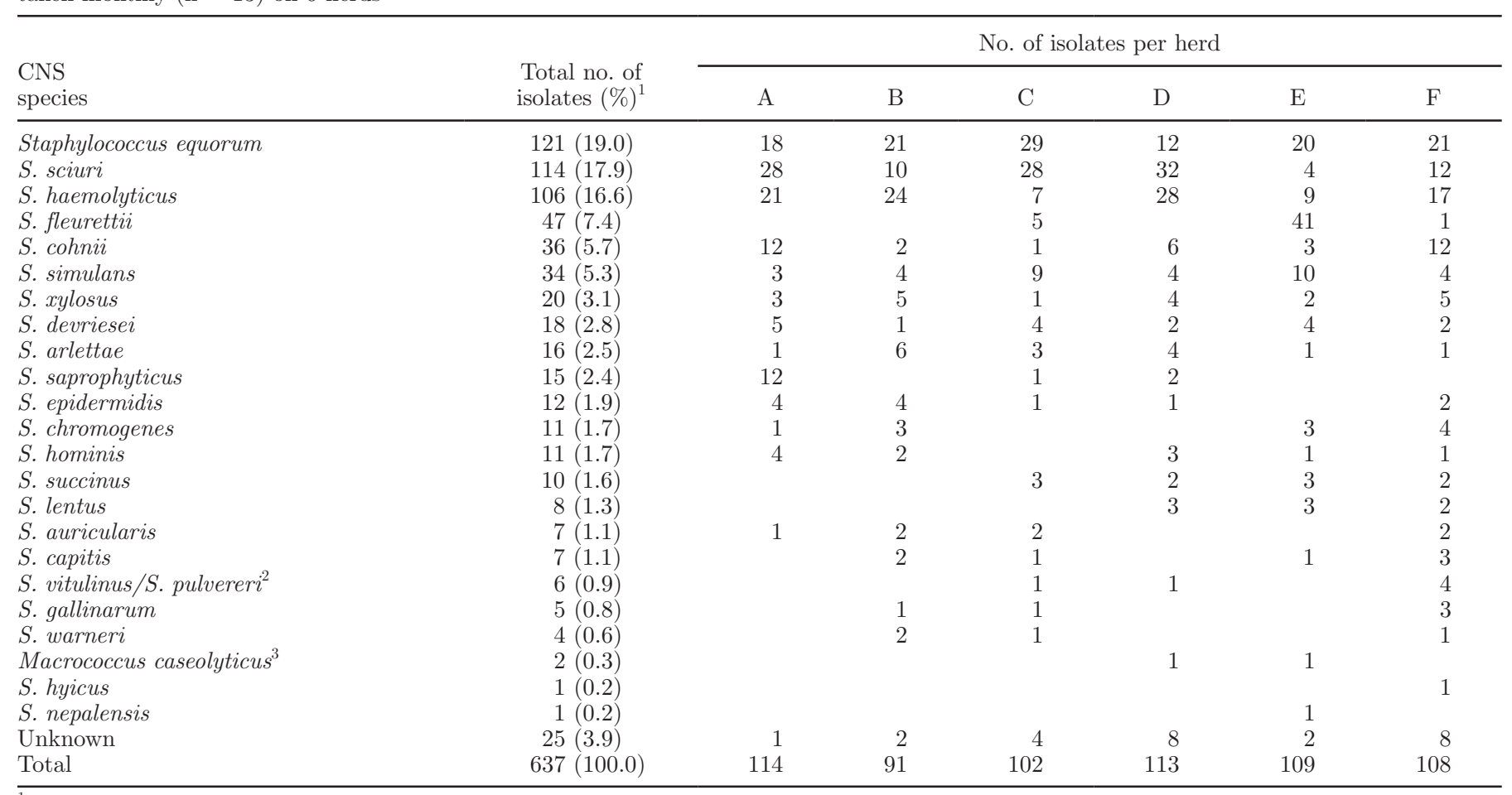

${ }^{1}$ Total number of isolates per species and respective proportion (\%) of all isolates $(\mathrm{n}=637)$.

${ }^{2} S$. vitulinus and $S$. pulvereri are synonyms for the same species.

${ }^{3}$ Staphylococcus caseolyticus has been reclassified as M. caseolyticus and is sporadically isolated from cattle.

CNS isolates were genotyped and identified to species level by means of AFLP, a well-validated and reproducible whole-genome based method (Piessens et al., 2010). This is in contrast to the majority of previous field studies on CNS in which phenotypic methods were generally used for species differentiation (Matos et al., 1991; Thorberg et al., 2009). In several studies, however, it has been demonstrated that phenotypic methods are insufficient for identification of CNS isolates from the bovine (Bes et al., 2000; Capurro et al., 2009; Sampimon et al., 2009). Currently, genotyping is the preferred method to gain accurate information on CNS at the species level (Zadoks and Watts, 2009). In the past, CNS from cows' environment have only been studied by using phenotypic methods (Matos et al., 1991) and as far as we know, their genotypes have never been compared with those of CNS causing IMI. Amplified fragment length polymorphism genotyping enables not only species identification, but also genotypic comparison of CNS isolates and tracking of the spread of specific CNS genotypes, which provides valuable information on epidemiology of these udder pathogens. Because different control practices are needed when either contagious or environmental pathogens cause a significant proportion of all IMI in a herd, determining the epidemiology of individual CNS species is useful for the dairy industry to prevent infections with particular more pathogenic CNS species.

According to our postulated IMI definition, only the CNS species $S$. chromogenes, $S$. haemolyticus, $S$. simulans, and $S$. epidermidis caused IMI in the studied cows. This is in line with other studies, where these species have also been isolated from IMI (Aarestrup and Jensen, 1997; Chaffer et al., 1999; Taponen et al., 2007), although other CNS species; for example, S. xylosus (Thorberg et al., 2009) and S. hyicus (Gillespie et al., 2009), have also been reported. Most CNS IMI detected in our study were persistent in nature, although this was largely due to the rather stringent definition for CNS IMI based on 3 consecutive monthly samples. No standard criteria exist for diagnosis of CNS IMI in the bovine udder, although attempts to define a general IMI definition have recently been published (Dohoo et al., 2011). This recent consensus is, however, based on weekly samplings, whereas we used monthly data. Because of the relatively large time interval between samplings and the drawbacks of bacterial culturing, the real number of IMI in our study is most likely underestimated, especially for IMI of short duration. Nevertheless, the effect of these transient 
Table 5. Distribution of the individual CNS species isolated from monthly sampled $(\mathrm{n}=13)$ niches on 6 dairy farms (high occurrence of individual species in a particular niche is indicated in bold)

\begin{tabular}{|c|c|c|c|c|c|c|}
\hline \multirow[b]{2}{*}{ CNS species } & \multicolumn{5}{|c|}{ No. $(\%)$ of isolates per niche ${ }^{1}$} & \multirow[b]{2}{*}{$\begin{array}{l}\text { Total no. } \\
(\%)^{2}\end{array}$} \\
\hline & Milk $^{3}$ & Air & $\begin{array}{l}\text { Slatted } \\
\text { floors }\end{array}$ & $\begin{array}{l}\text { Sawdust } \\
\text { cubicles }\end{array}$ & $\begin{array}{l}\text { Sawdust } \\
\text { stock }\end{array}$ & \\
\hline S. equorum & $2(1.6)$ & $61(49.6)$ & $28(22.8)$ & $22(17.9)$ & $10(8.1)$ & $123(16.0)$ \\
\hline S. sciuri & $1(0.9)$ & $14(12.2)$ & $43(37.4)$ & $40(34.8)$ & $17(14.8)$ & $115(14.9)$ \\
\hline S. chromogenes & $41(78.8)$ & $3(5.8)$ & $5(9.6)$ & $2(3.8)$ & $1(1.9)$ & $52(6.7)$ \\
\hline S. cohnii & $4(10.0)$ & $11(27.5)$ & $6(15.0)$ & $9(22.5)$ & $10(25.0)$ & $40(5.2)$ \\
\hline S. epidermidis & $16(57.1)$ & $1(3.6)$ & $4(14.3)$ & $5(17.9)$ & $2(7.1)$ & $28(3.6)$ \\
\hline S. devriesei & $2(10.0)$ & $7(35.0)$ & $4(20.0)$ & $3(15.0)$ & $4(20.0)$ & $20(2.6)$ \\
\hline S. xylosus & & $5(25.0)$ & $4(20.0)$ & & $11(55.0)$ & $20(2.6)$ \\
\hline S. saprophyticus & $4(21.1)$ & $3(15.8)$ & $1(5.3)$ & $4(21.1)$ & $7(36.8)$ & $19(2.5)$ \\
\hline S. arlettae & & $8(50.0)$ & $1(6.3)$ & $4(25.0)$ & $3(18.8)$ & $16(2.1)$ \\
\hline S. hominis & $5(31.3)$ & $3(18.8)$ & $1(6.3)$ & $6(37.5)$ & $1(6.3)$ & $16(2.1)$ \\
\hline S. vitulinus/S. pulvereri & & & $4(66.7)$ & $1(16.7)$ & $1(16.7)$ & $6(0.8)$ \\
\hline S. gallinarum & & & $3(60.0)$ & & $2(40.0)$ & $5(0.7)$ \\
\hline Macrococcus caseolyticus & $1(33.3)$ & $1(33.3)$ & $1(33.3)$ & & & $3(0.4)$ \\
\hline S. hyicus & & $1(100.0)$ & & & & $1(0.1)$ \\
\hline S. nepalensis & & & & & $1(100.0)$ & $1(0.1)$ \\
\hline Unknown & & $10(40.0)$ & $12(48.0)$ & $1(4.0)$ & $2(8.0)$ & $25(3.2)$ \\
\hline Total & $134(17.4)$ & $209(27.1)$ & $189(24.5)$ & $135(17.5)$ & $104(13.5)$ & $771(100.0)$ \\
\hline
\end{tabular}

${ }^{1}$ Distribution of isolates of individual CNS species over the sampled niches given in numbers and proportion (\%) of total number of isolates within the respective species.

${ }^{2}$ Total number of isolates per species and respective proportion $(\%)$ of all isolates $(\mathrm{n}=771)$.

${ }^{3}$ Isolates from quarter milk samples of monthly sampled cows in the 6 herds (10 cows/herd) yielding $\geq 300 \mathrm{cfu}$ of $\mathrm{CNS} / \mathrm{mL}$.

CNS IMI on general udder health is probably minor, whereas the long duration of undetected subclinical infections increases the effect on SCC and the possibility of spread of the causative bacteria. Although all CNS species isolated from milk in our study were evaluated using the same definition, striking differences were found among CNS species and only 4 were considered of particular interest. Persistence of $S$. chromogenes, $S$. haemolyticus, S. epidermidis, and S. simulans has been diagnosed in previous studies by repeated isolation of the same species from the same quarter (Aarestrup and Jensen, 1997; Chaffer et al., 1999; Thorberg et al., 2009). Our observations further confirm that particular CNS strains within these species, as evidenced by the repeated isolation of the same AFLP type, are able to survive and persist in the udder.

Comparing the prevalence of different CNS species between studies should be done with caution, as differences often exist in the identification methods used, definitions for CNS IMI, or sampling schedule. However, it can be assumed that distribution of CNS species infecting the udder varies between herds (this study; Gillespie et al., 2009; Thorberg et al., 2009). Part of this variation could be explained by factors such as type of germicide used for teat dipping (Hogan et al., 1987) or age of the cows (Matthews et al., 1992; Taponen et al., 2006). Between herds, marked differences were also seen in CNS species distribution in the environment, although farm and management characteristics of the herds included in our study were similar. This also indicates that currently unknown herd-level factors or environmental conditions determine the establishment of staphylococcal species in a dairy herd. In 2 studies in which extramammary CNS isolates have also been differentiated, it has been demonstrated that type of housing (White et al., 1989) and type of bedding (Matos et al., 1991) influence the distribution of CNS species found on body sites of heifers and in bedding samples, respectively. Although no attempt was made to quantify individual CNS species in the environment, we conclude that each dairy farm probably harbors its own CNS microbiota. To explain this remarkable variation in occurrence of particular CNS species, further study on the influence of different herd and environmental factors on CNS prevalence and distribution is required. 
The findings of our study suggest that CNS species are abundantly present in the studied type of dairy herds, but that their primary reservoirs differ according to species. For S. chromogenes and S. epidermidis, the udder was found as a main reservoir. These 2 species were rarely isolated from the environment and IMI probably originated from other sources; for example, the cow's skin, milkers' hands, or other cows. In our study, S. chromogenes caused the most and longest persistent subclinical IMI and was found to be the most likely cause of 2 clinical cases. As $S$. chromogenes is a commonly isolated mastitis pathogen (Aarestrup and Jensen, 1997; Gillespie et al., 2009; Sawant et al., 2009) able to induce an elevation in SCC as high as that seen for infections with the major pathogen $S$. aureus (Supré et al., 2011), its role in udder health might not be as minor as previously thought. Staphylococcus chromogenes has been isolated from udder skin, teat apices, and other body sites in previous studies (White et al., 1989; De Vliegher et al., 2003; Taponen et al., 2008). According to Taponen et al. (2008), this species is a typical skin opportunist. Unlike $S$. chromogenes, $S$. epidermidis is uncommon in normal bovine skin microbiota, but it is one of the most prevalent staphylococcal species on human skin and may be transmitted from milkers to cows (Thorberg et al., 2006).

Two CNS species (S. haemolyticus and S. simulans) were found that caused IMI and also survived well in the environment. In particular, S. haemolyticus caused a large proportion of all IMI and appeared to have a considerable environmental reservoir. In several studies, this species was not or was only rarely isolated from IMI (Matthews et al., 1992; Gillespie et al., 2009), whereas in others it has been found frequently (Chaffer et al., 1999; Thorberg et al., 2009). The apparent differences in $S$. haemolyticus prevalence could be due to either true variation in its occurrence or the difficulty in identifying this species. Among our S. haemolyticus isolates, 2 very distinct AFLP types were differentiated, 1 of which could only be identified by rpoB gene sequencing. Possibly, the latter type could lead to identification problems when using other methods. Within herds, similar AFLP types of $S$. haemolyticus were observed among isolates originating from environment and IMI, strongly indicating potential environmental sources for IMI with this species. Staphylococcus haemolyticus was also commonly isolated from the teat apices of the cows under study (G. Braem, B. Verbist, V. Piessens, S. De Vliegher, and L. De Vuyst, unpublished results), indicating its adaptability to various niches in the dairy herd. Staphylococcus simulans, on the other hand, is uncommon on cow skin and the source of IMI with this species is still unclear; S. simulans tends to cause more severe mastitis and predominates in studies conducted on clinical mastitis (Myllys, 1995; Waage et al., 1999). In this study, environmental $S$. simulans isolates mostly originated from slatted floors and used bedding, which might imply contamination of the environment by infected cows. In a study by Aarestrup et al. (1999), a variety of ribotypes of $S$. simulans have been recovered from IMI in the same herds and within different quarters of the same cows. The observed genetic diversity of infectious $S$. simulans ribotypes in that study might imply multiple environmental sources, although this has not yet been demonstrated.

The origin of all other CNS species isolated in our study was primarily environmental. In addition, 25 CNS were isolated from the environment that could not be identified by our AFLP method. These isolates could represent previously unknown CNS species; however, they were not studied further because of their overall low prevalence. In 2 other studies using molecular techniques for CNS differentiation, unidentifiable genetic profiles were also generated for several presumptive CNS isolates with transfer DNA-PCR (Supré et al., 2009) and AFLP (Taponen et al., 2006). Further study of these atypical isolates led to the characterization and description of 2 new CNS species, S. devriesei (Supré et al., 2010) and S. agnetis (Taponen et al., 2011). Surprisingly, some species that were mainly environmental in our study have been found to be significant causes of IMI in others; for example, S. xylosus (Thorberg et al., 2009), S. sciuri (Davidson et al., 1992), and $S$. cohnii (Supré et al., 2011). It can be speculated that when infection pressure is high or when immunity of cows is compromised, these CNS species may act as environmental opportunistic pathogens. In addition, it could be that some strains within these species are better adapted to cause infection. Despite prevention measures such as teat disinfection and dry cow therapy, prevalence of CNS infections in some herds is remarkably high for unknown reasons (Piepers et al., 2007; Schukken et al., 2009). In the past, only a few studies have been set up to identify possible reservoirs of CNS by comparing strains originating from mastitis with strains originating from other sources (Thorberg et al., 2006; Taponen et al., 2008). Knowledge on primary reservoirs of particular CNS species in herds (e.g., $S$. xylosus in sawdust stock) could be useful in prevention of CNS infections contracted from the environment. Our study was an attempt to identify potential environmental sources of CNS IMI. However, before we can demonstrate possible transmission routes of individual CNS species or identify reservoirs of strains causing 
IMI, clonal diversity within CNS species observed in the AFLP fingerprints should be further confirmed by (an)other molecular subtyping technique(s).

\section{CONCLUSIONS}

Distribution of CNS species in the milk and environment of cows differed among herds. Epidemiology of CNS infecting the udder varied among species. Staphylococcus chromogenes and S. epidermidis seemed to act more as host-adapted pathogens specialized in surviving in the udder, and the environment was not found as a likely source of IMI. Staphylococcus haemolyticus and S. simulans, on the other hand, had a considerable reservoir in the environment and could act as environmental opportunists.

\section{ACKNOWLEDGMENTS}

This research was funded by the Institute for the Promotion of Innovation through Science and Technology in Flanders (IWT-Vlaanderen, grant no. 60714). The authors thank Ann Vanhee (ILVO, Technology and Food Science Unit, Melle, Belgium) for her excellent laboratory support.

\section{REFERENCES}

Aarestrup, F. M., and N. E. Jensen. 1997. Prevalence and duration of intramammary infection in Danish heifers during the peripartum period. J. Dairy Sci. 80:307-312.

Aarestrup, F. M., H. D. Larsen, and N. E. Jensen. 1999. Characterization of Staphylococcus simulans strains isolated from cases of bovine mastitis. Vet. Microbiol. 66:165-170.

Barkema, H. W., Y. H. Schukken, T. J. G. M. Lam, M. L. Beiboer, H. Wilmink, G. Benedictus, and A. Brand. 1998. Incidence of clinical mastitis in dairy herds grouped in three categories by bulk milk somatic cell counts. J. Dairy Sci. 81:411-419.

Bes, M., V. Guerin-Faublee, H. Meugnier, J. Etienne, and J. Freney. 2000. Improvement of the identification of staphylococci isolated from bovine mammary infections using molecular methods. Vet. Microbiol. 71:287-294.

Bradley, A. J., K. A. Leach, J. E. Breen, L. E. Green, and M. J. Green. 2007. Survey of the incidence and aetiology of mastitis on dairy farms in England and Wales. Vet. Rec. 160:253-257.

Braem, G., S. De Vliegher, K. Supré, F. Haesebrouck, F. Leroy, and L. De Vuyst. 2011. (GTG)5-PCR fingerprinting for the classification and identification of coagulase-negative Staphylococcus species from bovine milk and teat apices: A comparison of type strains and field isolates. Vet. Microbiol. 147:67-74.

Capurro, A., K. Artursson, K. P. Waller, B. Bengtsson, H. EricssonUnnerstad, and A. Aspan. 2009. Comparison of a commercialized phenotyping system, antimicrobial susceptibility testing, and tuf gene sequence-based genotyping for species-level identification of coagulase-negative staphylococci isolated from cases of bovine mastitis. Vet. Microbiol. 134:327-333.

Chaffer, M., G. Leitner, M. Winkler, A. Glickman, O. Krifucks, E. Ezra, and A. Saran. 1999. Coagulase-negative staphylococci and mammary gland infections in cows. Zentralbl. Veterinarmed. B 46:707-712.

Davidson, T. J., I. R. Dohoo, A. W. Donald, H. Hariharan, and K. Collins. 1992. A cohort study of coagulase negative staphylococcal mastitis in selected dairy herds in Prince Edward Island. Can. J. Vet. Res. 56:275-280.

De Vliegher, S., H. Laevens, L. A. Devriese, G. Opsomer, J. L. M. Leroy, H. W. Barkema, and A. de Kruif. 2003. Prepartum teat apex colonization with Staphylococcus chromogenes in dairy heifers is associated with low somatic cell count in early lactation. Vet. Microbiol. 92:245-252.

Dohoo, I. R., J. Smith, S. Andersen, D. F. Kelton, and S. Godden. 2011. Diagnosing intramammary infections: Evaluation of definitions based on a single milk sample. J. Dairy Sci. 94:250-261.

Fitzgerald, J. R., W. J. Meaney, P. J. Hartigan, C. J. Smyth, and V. Kapur. 1997. Fine-structure molecular epidemiological analysis of Staphylococcus aureus recovered from cows. Epidemiol. Infect. 119:261-269.

Fox, L. K. 2009. Prevalence, incidence and risk factors of heifer mastitis. Vet. Microbiol. 134:82-88.

Gillespie, B. E., S. I. Headrick, S. Boonyayatra, and S. P. Oliver. 2009. Prevalence and persistence of coagulase-negative Staphylococcus species in three dairy research herds. Vet. Microbiol. 134:65-72.

Hogan, J. S., K. L. Smith, D. A. Todhunter, and P. S. Schoenberger. 1988. Rate of environmental mastitis in quarters infected with Corynebacterium bovis and Staphylococcus species. J. Dairy Sci. $71: 2520-2525$.

Hogan, J. S., D. G. White, and J. W. Pankey. 1987. Effects of teat dipping on intramammary infections by staphylococci other than Staphylococcus aureus. J. Dairy Sci. 70:873-879.

Lam, T. J. G. M., Y. H. Schukken, J. H. vanVliet, F. J. Grommers, M. J. M. Tielen, and A. Brand. 1997. Effect of natural infection with minor pathogens on susceptibility to natural infection with major pathogens in the bovine mammary gland. Am. J. Vet. Res. 58:17-22.

Lüthje, P., and S. Schwarz. 2006. Antimicrobial resistance of coagulase-negative staphylococci from bovine subclinical mastitis with particular reference to macrolide-lincosamide resistance phenotypes and genotypes. J. Antimicrob. Chemother. 57:966-969.

Mason, W. J., J. S. Blevins, K. Beenken, N. Wibowo, N. Ojha, and M. S. Smeltzer. 2001. Multiplex PCR protocol for the diagnosis of staphylococcal infection. J. Clin. Microbiol. 39:3332-3338.

Matos, J. S., D. G. White, R. J. Harmon, and B. E. Langlois. 1991. Isolation of Staphylococcus aureus from sites other than the lactating mammary gland. J. Dairy Sci. 74:1544-1549.

Matthews, K. R., R. J. Harmon, and B. E. Langlois. 1991. Effect of naturally occurring coagulase-negative staphylococci infections on new infections by mastitis pathogens in the bovine. J. Dairy Sci. 74:1855-1859.

Matthews, K. R., R. J. Harmon, and B. E. Langlois. 1992. Prevalence of Staphylococcus species during the periparturient period in primiparous and multiparous cows. J. Dairy Sci. 75:1835-1839.

Myllys, V. 1995. Staphylococci in heifer mastitis before and after parturition. J. Dairy Res. 62:51-60.

National Mastitis Council. 1999. Laboratory Handbook on Bovine Mastitis. National Mastitis Council Inc., Madison, WI.

National Mastitis Council. 2009. Recommended Mastitis Control Program. National Mastitis Council Inc., Madison, WI. http://www. nmconline.org/docs/NMCchecklistInt.pdf.

Nickerson, S. C., and R. L. Boddie. 1994. Effect of naturally occurring coagulase-negative staphylococcal infections on experimental challenge with major mastitis pathogens. J. Dairy Sci. 77:2526-2536.

Park, J. Y., L. K. Fox, K. S. Seo, M. A. McGuire, Y. H. Park, F. R. Rurangirwa, W. M. Sischo, and G. A. Bohach. 2011. Detection of classical and newly described staphylococcal superantigen genes in coagulase-negative staphylococci isolated from bovine intramammary infections. Vet. Microbiol. 147:149-154.

Piepers, S., L. De Meulemeester, A. de Kruif, G. Opsomer, H. W. Barkema, and S. De Vliegher. 2007. Prevalence and distribution of mastitis pathogens in subclinically infected dairy cows in Flanders, Belgium. J. Dairy Res. 74:478-483.

Piepers, S., G. Opsomer, H. W. Barkema, A. de Kruif, and S. De Vliegher. 2010. Heifers infected with coagulase-negative staphylococci in early lactation have fewer cases of clinical mastitis and 
higher milk production in their first lactation than non-infected heifers. J. Dairy Sci. 93:2014-2024.

Piepers, S., K. Peeters, G. Opsomer, H. W. Barkema, K. Frankena and S. De Vliegher. 2011. Pathogen group specific risk factors at the herd, heifer and quarter level for intramammary infections in early lactating dairy heifers. Prev. Vet. Med. doi:10.1016/j. prevetmed.2011.02.010.

Piessens, V., K. Supre, M. Heyndrickx, F. Haesebrouck, S. De Vliegher, and E. Van Coillie. 2010. Validation of amplified fragment length polymorphism genotyping for species identification of bovine associated coagulase-negative staphylococci. J. Microbiol. Methods 80:287-294.

Rainard, P., and B. Poutrel. 1988. Effect of naturally-occurring intramammary infections by minor pathogens on new infections by major pathogens in cattle. Am. J. Vet. Res. 49:327-329.

Rendos, J. J., R. J. Eberhart, and E. M. Kesler. 1975. Microbial populations of teat ends of dairy cows and bedding materials. J. Dairy Sci. 58:1492-1500.

Sampimon, O. C., R. N. Zadoks, S. De Vliegher, K. Supre, F. Haesebrouck, H. W. Barkema, J. Sol, and T. J. G. M. Lam. 2009. Performance of API Staph ID 32 and Staph-Zym for identification of coagulase-negative staphylococci isolated from bovine milk samples. Vet. Microbiol. 136:300-305.

Sawant, A. A., B. E. Gillespie, and S. P. Oliver. 2009. Antimicrobial susceptibility of coagulase-negative Staphylococcus species isolated from bovine milk. Vet. Microbiol. 134:73-81.

Schukken, Y. H., R. N. Gonzalez, L. L. Tikofsky, H. F. Schulte, C. G. Santisteban, F. L. Welcome, G. J. Bennett, M. J. Zurakowski, and R. N. Zadoks. 2009. CNS mastitis: Nothing to worry about? Vet. Microbiol. 134:9-14.

Supré, K., S. De Vliegher, I. Cleenwerck, K. Engelbeen, S. Van Trappen, S. Piepers, O. C. Sampimon, R. N. Zadoks, P. De Vos, and F. Haesebrouck. 2010. Staphylococcus devriesei sp. nov., isolated from teat apices and milk of dairy cows. Int. J. Syst. Evol. Microbiol. 60:2739-2744.

Supré, K., S. De Vliegher, O. C. Sampimon, R. N. Zadoks, M. Vaneechoutte, M. Baele, E. De Graef, S. Piepers, and F. Haesebrouck. 2009. Technical note: Use of transfer RNA-intergenic spacer PCR combined with capillary electrophoresis to identify coagulase-negative Staphylococcus species originating from bovine milk and teat apices. J. Dairy Sci. 92:3204-3210.

Supré, K., F. Haesebrouck, R. N. Zadoks, M. Vaneechoutte, S. Piepers, and S. De Vliegher. 2011. Some CNS species are affecting udder health more than others. J. Dairy Sci. 94:2329-2340. doi:10.3168/ jds.2010-3741.

Taponen, S., J. Bjorkroth, and S. Pyorala. 2008. Coagulase-negative staphylococci isolated from bovine extramammary sites and intramammary infections in a single dairy herd. J. Dairy Res. 75:422429.

Taponen, S., J. Koort, J. Bjorkroth, H. Saloniemi, and S. Pyorala. 2007. Bovine intramammary infections caused by coagulase-negative staphylococci may persist throughout lactation according to amplified fragment length polymorphism-based analysis. J. Dairy Sci. 90:3301-3307.

Taponen, S., H. Simojoki, M. Haveri, H. D. Larsen, and S. Pyorala. 2006. Clinical characteristics and persistence of bovine mastitis caused by different species of coagulase-negative staphylococci identified with API or AFLP. Vet. Microbiol. 115:199-207.

Taponen, S., K. Supré, V. Piessens, E. Van Coillie, S. De Vliegher, and J. Koort. 2011. Staphylococcus agnetis sp. nov., a coagulasevariable species from bovine subclinical and mild clinical mastitis. Int. J. Syst. Evol. Microbiol. doi:10.1099/ijs.0.028365-0.

Tenhagen, B. A. G. Koster, J. Wallmann, and W. Heuwieser. 2006. Prevalence of mastitis pathogens and their resistance against antimicrobial agents in dairy cows in Brandenburg, Germany. J. Dairy Sci. 89:2542-2551.

Thorberg, B. M., M. L. Danielsson-Tham, U. Emanuelson, and K. P. Waller. 2009. Bovine subclinical mastitis caused by different types of coagulase-negative staphylococci. J. Dairy Sci. 92:4962-4970.

Thorberg, B. M., I. Kuhn, F. M. Aarestrup, B. Brandstrom, P. Jonsson, and M. L. Danielsson-Tharn. 2006. Pheno- and genotyping of Staphylococcus epidermidis isolated from bovine milk and human skin. Vet. Microbiol. 115:163-172.

Waage, S., T. Mork, A. Roros, D. Aasland, A. Hunshamar, and S. A. Odegaard. 1999. Bacteria associated with clinical mastitis in dairy heifers. J. Dairy Sci. 82:712-719.

White, D. G., R. J. Harmon, J. E. S. Matos, and B. E. Langlois. 1989 Isolation and identification of coagulase-negative Staphylococcus species from bovine body sites and streak canals of nulliparous heifers. J. Dairy Sci. 72:1886-1892.

Zadoks, R. N., and J. L. Watts. 2009. Species identification of coagulase-negative staphylococci: Genotyping is superior to phenotyping. Vet. Microbiol. 134:20-28. 